\title{
Advanced EFL Learners' Beliefs about Pronunciation Teaching
}

\author{
Sharif M. Alghazo ${ }^{1}$ \\ ${ }^{1}$ Department of Linguistics, University of Jordan, Amman, Jordan \\ Correspondence: Sharif M. Alghazo, Department of Linguistics, University of Jordan, Amman, Jordan. Tel: \\ 962-6535-5000 (Extension 24709). E-mail: alghazo.sharif@yahoo.com
}

Received: May 7, 2015 Accepted: June 18, 2015 Online Published: October 27, 2015

doi:10.5539/ies.v8n11p63 URL: http://dx.doi.org/10.5539/ies.v8n11p63

\begin{abstract}
This paper explores EFL learners' beliefs about English pronunciation teaching and aims to provide insights into current teaching practices of English pronunciation at both college and university levels. To this end, the study sought to elicit the beliefs of a group of 71 third- and fourth-year EFL learners majoring in English at a university college in Saudi Arabia about crucial aspects of pronunciation teaching. The study utilized a survey containing five-point Likert scale items as well as multiple-choice questions. Open-ended questions were also included in order to gain fuller understanding of students' views. Data were thematically analyzed and consequently categorized into five major areas: course design, language of instruction, learning and teaching style, types of feedback, and nativeness of teachers. It was found that students in this study context are cognizant of the value of learning English pronunciation, and of what they find useful and less useful. Students also proved willing to help improve pronunciation instruction by providing helpful perspectives on the proper way, at least in their views, to present this sub-skill.
\end{abstract}

Keywords: bilingual teaching, course design, English pronunciation, learner beliefs, pronunciation teaching, teaching approach

\section{Introduction}

The area of second language (L2) pronunciation has long been a neglected one in English language teaching (ELT). Porter (1999), for example, confirmed that the teaching of pronunciation received little attention either in pedagogical theory or materials design. Over the past 15 years, similar arguments have been set forth (see, for example, Breitkreutz, Derwing, \& Rossiter, 2001; Burgess \& Spencer, 2000; Couper, 2009; Derwing, 2010; Derwing \& Munro, 2005; Macdonald, 2002; Murphy, 2014; Pawlak, 2010), with many researchers calling for an urgent need of further investigation. One dimension of pronunciation teaching which has received hardly any attention to date is that of learner cognitions or beliefs about the way teachers of L2 pronunciation should approach this sub-skill. As Pawlak, Mystkowska-Wiertelak, and Bielakthere (2015, p. 5) note: "there has [sic]been surprisingly few empirical investigations that would have attempted to tap learners' or teachers' beliefs and preferences concerning pronunciation teaching". The present study aims to respond to this assertion and to advance research in this neglected area.

\section{Literature Review}

\subsection{Beliefs about Foreign Language Learning}

It is well-established that learner and teacher cognitions about foreign language learning and teaching have a paramount influence on both teaching practices and curriculum design (e.g., Borg, 2006; Horwitz, 2008). A significant component of cognitions is the beliefs that learners and teachers hold about different aspects of language learning and teaching. Wenden (1986, p. 5) defines learner beliefs as "opinions which are based on experience and the opinions of respected others, which influence the way they act". In this sense, learner beliefs about foreign language learning and teaching incorporate understandings and experiences which are likely to inform their perceptions of learning.

Research on the value of learner beliefs about language instruction as a whole has found that these beliefs have a great impact on learners' achievements in language classrooms. Bernat (2008), for example, asserts that learner beliefs were found to play a role in shaping the psycho-cognitive processes of learning with such influence leading to inform their actions in the classroom. Moreover, learner beliefs were found to have a link to both motivation (Bernat, 2008) and anxiety (Young, 1991) which are influential variables into learner achievements in 
L2. Also, learner beliefs were found to impact on the use of language learning strategies; the latter being of invaluable importance to learning success (see, for example, Cohen, 1998; Oxford, 1990; White, 2008; Yang, 1999). Space does not permit an extensive review of research on the value of language learning strategies, but attention should be paid to some studies that showed positive effects of learning strategies on developing language skills such as Li and Chun (2012) in the area of reading literacy, Vandergrift (1999) in writing, and Calka (2011) and Pawlak (2008) in pronunciation.

\subsection{Beliefs about Pronunciation Instruction}

Beliefs about pronunciation instruction have been little explored. Existing studies have focused, in the main, on exploring teacher beliefs about pronunciation teaching (see, for example, Baker, 2011; Lin, 2010) and relating their beliefs to teaching practices in the classroom. Some studies have paid attention to investigating learner beliefs about L2 pronunciation learning (e.g., Cenoz \& Garcia-Lecumberri, 1999). But, as Baker and Murphy (2011) point out, studies into learner beliefs about L2 pronunciation teaching are missing from mainstream literature on pronunciation teaching and learning.

There have been a number of studies which explored teacher beliefs about L2 pronunciation instruction in both English as a Foreign Language (EFL)and English as a Second Language (ESL) classrooms. Baker (2011), for example, investigated the relationship between the beliefs and practices of five experienced ESL teachers in regard to the ways they address L2 pronunciation, and found that the teachers share a feeling of insecurity when it comes to teaching this area. The limitations felt by many teachers when it comes to pronunciation have been similarly documented in various contexts by Fraser (2000) in Australia; Burgess and Spencer (2000) in the UK; Foote, Holtby, and Derwing (2011) in Canada; and Derwing (2008) in the USA.

If we turn to studies that explored learner beliefs about L2 pronunciation, we find that these have highlighted issues such as the importance of learning L2 pronunciation (Rajadurai, 2001), attitudes towards explicit pronunciation instruction (Couper, 2003), preferred models of pronunciation learning (Szpyra-Kozlowska, 2008), and perceptions of the advantages and disadvantages of native English speaking teachers (NESTs) and non-native English speaking teachers (NNESTs) in relation to pronunciation teaching (Ma, 2012). However, learner beliefs about and preferences towards various teaching approaches and their involvement in course design have relatively received little attention so far. As Baker (2014) argues, "research into current pronunciation-oriented teaching practices of L2 instructors is long overdue" (p. 139). This study hopes to contribute to the field by shedding light on Saudi EFL learners' perspectives in regard to the teaching approaches followed in their $\mathrm{L} 2$ pronunciation classes.

\subsection{Approaches to Pronunciation Teaching}

Prior to discussing the various approaches to teaching L2 pronunciation, it is worth a brief conceptualization of the term 'approach' as it is used in this study. The term 'approach' is often used interchangeably with other relevant concepts such as 'method', 'technique', or 'procedure'. To clarify the distinction, it is useful to refer to Richards and Rodgers's (2001) model in which they build on Anthony's (1963) hierarchical framework of approach, method, and technique. Richards and Rodgers (2001) argue that an approach should be realized in a method which is often implemented by procedures. However, they treat an approach and a method at the level of design; that is, involving decisions about the material content, the syllabus objectives, and the roles of teachers and learners. In this broad sense, a teaching approach refers to the general principles or theories that underpin a teaching method and thus inform the teaching techniques or procedures used in the classroom. With this in mind, it is clear that a teaching approach does not only refer to the teaching methods and strategies, but rather it is a collective term that includes many other relevant matters such as course design, teaching materials, language of instruction, and the roles and characteristics of language teachers. Each of these issues plays a key role in determining the kinds of strategies, techniques or procedures to be used in language classrooms.

To return to the principal concern of this section, viz. approaches to L2 pronunciation teaching, mainstream literature on this area does not present one whole approach claimed to be successful in the language classroom relying on empirically-informed research. Various, and sometimes contradictory, teaching approaches to L2 pronunciation have been offered by teachers and researchers in the field who - based on their experiences and intuitions (see, for example, Levis, 2005)-proposed them as the most effective in teaching pronunciation. This is not to say that there should be a consensus on the most appropriate approach to the teaching of L2 pronunciation and calling for this is simply "foolish" according to Yates and Zielinski $(2009$, p. 19) because "there is no one recipe for success in any kind of teaching" due to variation in contexts and individual learners. Therefore, manifold issues are usually taken into account to decide on the most appropriate approach in a teaching context. Among these are the teaching setting; institutional constraints; and learners' levels of proficiency in the L2, their 
goals of learning, and most importantly their beliefs about various aspects of pronunciation.

In literature on pronunciation teaching, a distinction is often made between 'bottom-up' and 'top-down' approaches. These are important because they not only refer to methods and strategies, but also can determine the course design, teaching materials, and instructional constraints. The traditional 'bottom-up' approach is based on raising students' awareness of first the language sounds in isolation, then moving on to the formation of syllables as sequences of sounds, and finally towards extended speech in the form of utterances and sentences; it is thus called a "building block" approach to pronunciation instruction (Goodwin, 2005). The approach has been questioned especially with the emergence of research demonstrating the vital role of suprasegmentals in achieving intelligibility and comprehensibility among L2 users (e.g., Chela-Flores, 2001; Celce-Murcia, Brinton, Goodwin, \& Griner, 2010; Derwing, Munro, \&Wiebe, 1998; Munro \& Derwing, 1995; Keys, 2000). The 'top-down' approach, on the other hand, places more emphasis on suprasegmentals by instructing students on stress, rhythm and intonation prior to focusing upon individual sounds. This approach was in part a response to studies which established the significance of suprasegmentals in successful communication, as noted above (see, also, Hahn, 2004; Field, 2005).

With these conflicting views on various approaches to teaching L2 pronunciation in mind, teachers are often left unguided on how best to approach this area. Therefore, experts in the field began to call for a more-balanced approach where both segmentals and suprasegmentals receive attention in the language classroom (see, for example, Celce-Murcia et al., 2010; Goodwin, 2001; Kennedy, 2008). These scholars and others assert that deciding on which features should be instructed first is left to teachers who-based on various factors such as students' level of proficiency and the teaching context-can design a course that meets their students' needs and expectations. Among the influencing factors also are students' goals of learning and their future ways of using the L2. This necessitates studies such as the present one that focus primarily on obtaining students' perspectives in order to create better teaching plans and appropriate instructional practices.

\section{Research Questions}

Given the scarcity of research on learner beliefs about L2 pronunciation instruction, the study seeks to explore the question: How do tertiary-levelEFL learners in Saudi Arabia perceive the teaching approach(s) adopted in their L2 pronunciation classes? This will be addressed through the following three research questions:

1) What perspectives do students have on the course design of L2 pronunciation subjects?

2) What do students think of their teachers' ways of approaching L2 pronunciation?

3) How do students perceive the roles of NESTs and NNESTs in regard to pronunciation instruction?

\section{Methods}

\subsection{Participants}

In order to investigate the study questions, I solicited the participation of a group of 71 EFL students, who were majoring in English and were enrolled in a four-year BA program at a university college in Saudi Arabia. They were all males because the setting is a male-only institution. All were aged between $21-25$ years. Almost $17 \%$ of the participants were in the third year of their degree while the rest were in the fourth year (see Table 1 below). Participants' proficiency levels in the target language were obtained through a self-evaluating scale ranging from 1 to 5 where 1 refers to very good, 3 to average, and 5 to poor (see Table 2 below). Participants provided a mean of $2.39 \%$ for their proficiency level, which shows that they are just under the intermediate level of proficiency.

Table 1. Demographic information about participants

\begin{tabular}{lcc}
\hline Year of Study & No. of Students (\%) & Age \\
\hline 3rd Year & $12(16.9 \%)$ & $21-25$ \\
4th Year & $59(83.1 \%)$ & $21-25$ \\
\hline
\end{tabular}


Table 2. Self-evaluation of students' proficiency levels

\begin{tabular}{cccccc}
\hline \multicolumn{6}{l}{ How would you rate your own English pronunciation ability? } \\
\hline 1 & 2 & 3 & 4 & 5 & \\
$($ very good) & $($ good) & (average) & (fair) & (poor) & Mean \\
$7(9.86 \%)$ & $38(53.5 \%)$ & $18(25.35 \%)$ & $7(9.86 \%)$ & $1(1.4 \%)$ & $2.39 \%$ \\
\hline
\end{tabular}

\subsection{Instrument}

A specifically-designed self-administered questionnaire (see Appendix) was used to collect data from the participants. The questionnaire consisted of two sections: The first collected background information about participants, including age, year of study, and number of pronunciation subjects being studied; and the second elicited participants' beliefs about the teaching approach and other relevant issues via a five-point Likert Scale (Strongly Agree $=1$, Strongly Disagree $=5$ ) as well as some multiple-choice questions. Open-ended questions were also included to provide opportunity for further explanation of students' responses. In order to assist reliability and in light of the relatively low English proficiency level of students, the survey was translated into Arabic by the researcher.

\subsection{Procedures}

The researcher, who was a teacher of English pronunciation at the time of data collection at the study context, discussed with the students the possibility of participating in a research study about their pronunciation instruction. The students were made aware of the way the research would be carried out in terms of methods and questions. They were also assured that taking part in this study would not in any way affect their grades or achievements in the subjects; and that they could leave the study at any time and without explanation. The researcher confirmed to students that data would be confidential and only be used for the purpose of this study. Of 84 students in the two classes chosen, 71 agreed to take part in this study by signing a consent form. The questionnaire was distributed in class by the researcher and students were given the time to respond to each item. Participants' responses were then translated into English for the purpose of data analysis. The data were analyzed thematically and categorized into five key issues: course design, language of instruction, learning and teaching style, types of feedback, and nativeness of teachers.

\section{Results}

The main research question asked how do tertiary-level EFL learners in Saudi Arabia perceive the teaching approach(s) adopted in their L2 pronunciation classes? As noted in the literature review, a 'teaching approach' involves several components in addition to actual teaching methods and strategies, such as course design, teaching materials, and language of instruction. Here, student participants described the course design for pronunciation subjects by stating that the course is entirely addressing segmentals with very minimal attention given to syllable structure. All participants noted that there is only one subject in the curriculum that focuses on the teaching of L2 pronunciation, and which specifically addresses the production and perception of consonant and vowel sounds. However, when asked about whether they find this amount of instruction (measured by the existence of only one subject) beneficial in developing their pronunciation abilities, the majority of participants $(61.9 \%)$ agreed or strongly agreed that the amount is not enough to develop their pronunciation skills while $28.1 \%$ of participants thought that it is enough to develop their pronunciation; $10 \%$ of participants were not sure (see Table 3 below).

Table 3. Students' views on course design

\begin{tabular}{lccc}
\hline Statement & A or SA (\%) & N & D or SA \\
\hline The amount of instruction is not enough to develop good pronunciation & $44(61.9 \%)$ & $7(10 \%)$ & $20(28.1 \%)$ \\
\hline
\end{tabular}

Note. $\mathrm{A}=$ Agree, $\mathrm{SA}=$ Strongly Agree, $\mathrm{N}=$ Neutral, $\mathrm{D}=$ Disagree, $\mathrm{SD}=$ Strongly Disagree.

Further in relation to the course design, student participants were also asked their views on the features or aspects of L2 pronunciation that should be included in the pronunciation course. Here, a majority of participants $(85.92 \%)$ reported their preference to learn aspects that only cause communication problems while only $11.26 \%$ of participants reported their willingness to attend a comprehensive course that would include most aspects of L2 
pronunciation; $2.81 \%$ of participants did not answer the question (see Figure 1 below). Such perspectives on the influence of pronunciation instruction as well as on the features that should be taught in a course are indeed helpful in deciding on the teaching approach.

\section{Course design}

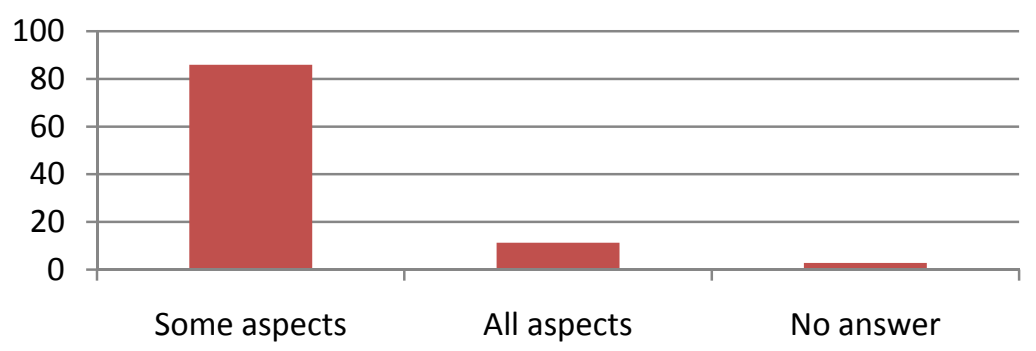

Figure 1. Students' views on course design

When asked about their preferencesfor the language of instruction used in pronunciation classes, students' responses weighed heavily towards 'code-switching' between English and Arabic, with the great majority of participants $(88.75 \%)$ preferring that teachers use a mix of the two languages in their explanation and discussion while only some $(8.45 \%)$ wanted teachers to use only Englishin pronunciation classes; $2.8 \%$ of students did not answer this question (see Figure 2 below). This finding is interesting in that it gives support to studies which focused on the significance of bilingual teaching in ESL and EFL classrooms (see, for example, Ellis, 2004; Forman, 2010, 2012), and may be attributed to the level of proficiency that students have in the L2.

\section{Language of instruction}

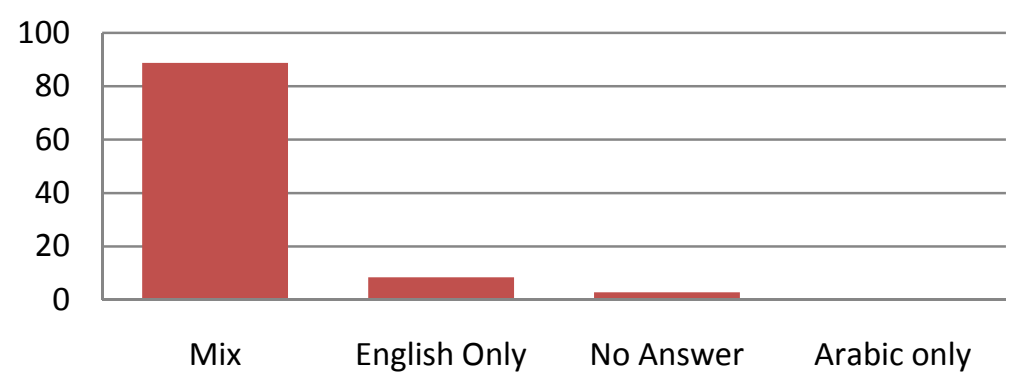

Figure 2. Students' preferences for the language of instruction

The second research question asked what do students think of their teachers' ways of approaching L2 pronunciation? Here, students were asked about two related issues: teaching style, and the provision of feedback.

In relation to teaching style, it is noteworthy that this factor is highly relevant to students' learning styles, as for optimum learning to occur, the two should be in harmony. Here, students were asked whether they prefer a sensing or an intuitive learning style (Myers \& Myers, 1980). That is, whether they prefer to practice L2 pronunciation first and receive teachers' explanations after that (this is sometimes called 'practice-to-theory') or they would prefer to receive teachers' explanations and discussions before practicing (it is sometimes referred to as 'theory-to-practice'). The large majority of participants $(84.5 \%)$ indicated their preference for an intuitive learning and teaching style while only $8.45 \%$ of participants preferred a sensing learning and teaching style; $7.04 \%$ of participants did not answer the question (see Figure 3 below). Again, this may be indicative of the level of knowledge students have about L2 pronunciation that they believe they muststart from the very beginning by receiving explanation of pronunciation before practicing it. Although this intuitive approach is a more traditional mode of teaching, it is argued that teachers "have to relate their own teaching style to that of their student 
teachers and teach student teachers to adapt to the learning styles of their future pupils" Tubić and Hamiloğlu (2009, p. 133).

\section{Learning and teaching style}

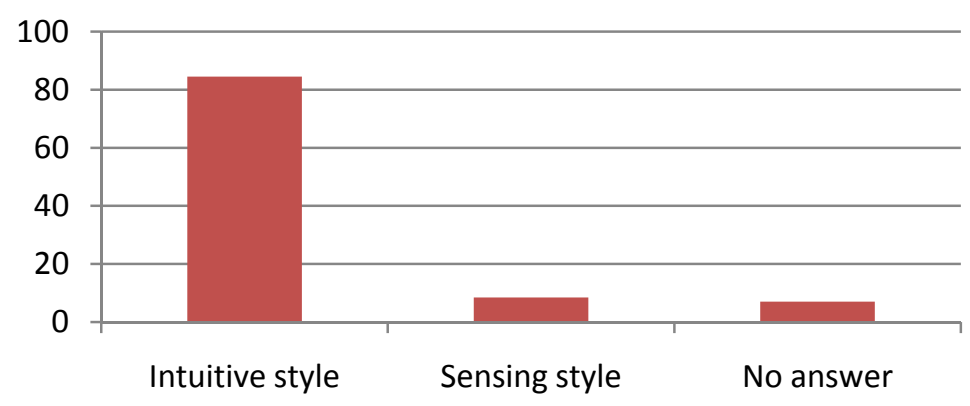

Figure 3. Students' preferences for learning and teaching styles

As for students' views on and preferences for the type of feedback provided by the teacher on their mistakes in pronunciation, it was found that a majority of student participants $(85.92 \%)$ agreed that immediate corrective feedback from the teacher is more useful, so that "students do not commit the same error again", as one student put it. On the other hand, only $12.67 \%$ of participants preferred that teachers provide delayed corrective feedback; that is, after the task is completed; one student did not answer the question (see Figure 4 below). Students' preference towards receiving immediate corrective feedback by the teacher is surprising because this is somehow inconsistent with psychological theories stating that one's ego may not accept others' critical judgments (see, for example, Brown, 2007) which are here in the form of corrective feedback. However, this finding is in line with those obtained in some previous pronunciation studies where students favored receiving immediate corrective feedback (e.g., Baker, 2011).

\section{Type of feedback}

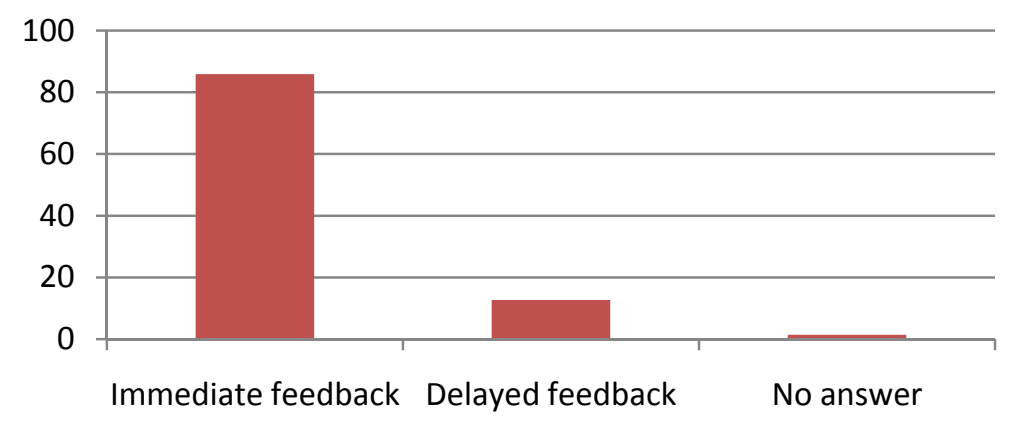

Figure 4. Students' preferences for the type of feedback

The last research question asked how do students perceive the roles of NESTs and NNESTs in regard to pronunciation instruction? Results showed that a small majority of student participants (52.12\%) preferred NNESTs to be involved in the teaching of L2 pronunciation, whereas $45.07 \%$ of participants showed preference towards NESTs; and 2.81\% were not sure (see Figure 5 below). 


\section{Nativeness of teachers}

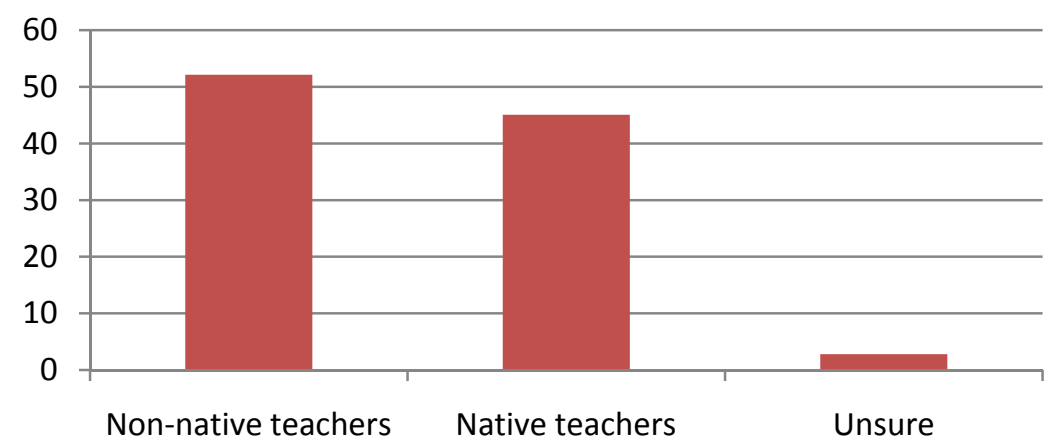

Figure 5. Students' views on the nativeness of teachers

For this particular question, it was interesting to elicit the reasons that led students to such responses through the open-ended question provided. Students' answers did not vary greatly, but were focused on some points. Students who preferred to be taught by NNESTs gave reasons such as "we can communicate better with NNESTs because of their shared first language" (S1); "NNESTs provide examples in Arabic which makes it easier for us to understand" (S2); "because this subject is new to us, some terminology may be strange to me, so NNESTs can explain these in Arabic" (S3); "I have experienced learning from NESTs and I found it difficult to understand their accent, so for this stage we are in, I think it is better to learn from NNESTs" (S4); and finally "an Arabic-speaking teacher will understand exactly what I need to learn from this subject because he knows Arab learners' problems" (S5). On the other hand, students who preferred to be taught by NESTs reported their own reasons for their choice such as "NESTs make us learn the "original' version of the language" (S6); "NESTs provide accurate pronunciation of words, so we will not have any confusion" (S7); "some NNESTs speak with an accent which makes it difficult for us to get the accurate pronunciation" (S8); and finally "NESTs are guaranteed!" (S9).

An interesting point about the results presented above is the very low number of students who either were unsure of their answer or who did not answer the question at all. This suggests that student participants are aware of the importance of this sub-skill of English and appear willing to provide feedback to researchers which can ultimately boost the quality of teaching in this area. Therefore, this paper tries to put the ball in the court of educators and administrators in this study context as well as in other similar contexts in Saudi Arabia to start rethinking the teaching of $\mathrm{L} 2$ pronunciation because it is one of the most important sub-skills required to communicate in L2 efficiently.

\section{Discussion}

The main aim of this paper is twofold: to report the results of the present study, and to argue for more engagement of students in decision-making processes, particularly in regard to their language learning. Results reported in the previous section provided significant insights into the process of pronunciation teaching in this EFL context which may be generalized to similar other contexts in the Arab world and possibly worldwide. The first insight relates to the design of pronunciation subjects: Students reported clear dissatisfaction with both the amount of tuition given to pronunciation teaching and with the balance of features that are covered. It is indeed reassuring that students affirm the importance of learning pronunciation through their feedback. Such an insight cannot be overlooked for, as Benjamin (2005) argues, ignoring students' desires and expectations when designing courses means that "we relegate them to a role of passivity" (p. 146), whereas if we engage students with our course design-by learning their goals and attitudes-we can lead students to develop self-responsibility and autonomy in the learning process.

What is also important in regard to student motivation is their willingness to provide solutions to course design problems. This was apparent in students' reported preference to follow a fluency-based approach (i.e., one that focuses only on features that cause communication problems) as opposed to an accuracy-based approach (i.e., one which focuses on all features of pronunciation) in pronunciation teaching as a way of overcoming the obstacles that teachers may encounter in approaching pronunciation. One such obstacle relates to a widely reported lack of time allocated to pronunciation classes (see, for example, Gilbert, 2008). Here, student 
participants preferred that teachers adopt an approach that focuses on features which may cause communication difficulties for Arab learners of English, rather than focusing on every part in the traditional inventory of sounds. These results provide support to Levis' (2007) argument that pronunciation teaching which is based on an accuracy-oriented approach is outdated because students' goals of learning the L2 have changed in consistency with current awareness of the global spread of English and the use of English as a Lingua Franca (ELF), the latter which gives greater attention to intelligibility rather than native-likeness as a possible and achievable goal.

A further issue that is worth highlighting relates to the use of first language (L1) in English pronunciation classes. Students' preferences here, although perhaps surprising, can be attributed to their realistic self-evaluation of their abilities in pronunciation and in the L2 more broadly. The use of L1 in L2 classrooms has been a subject of hot debate in the last few decades and has been the concern of several studies focusing on this issue. For example, Forman (2007)-drawing on Cook's $(1999,2003)$ multi-competence model-makes a strong case for the value of using L1 in L2 classrooms by examining an authentic episode of bilingual teaching in an EFL context where, as in this study, bilingual teaching was seen as a means of addressing students' low proficiency level. Student participants' preference for using 'code-switching' as a suitable way to address pronunciation features is also seen to be indicative of their awareness of and strong motivation to improve their pronunciation abilities. Such expectations are promising, as noted earlier, in that students are willing to state their views in the knowledge that this may assist the quality of course design and teaching practices in this area.

Of importance also is the answer to the second research question related to students' beliefs about the way their teachers teach L2 pronunciation. First and in regard to learning and teaching styles, students voiced their preference for an intuitive style by stating that they would like to learn different aspects of pronunciation by receiving teachers' explanation prior to student production. Although, as noted earlier, this intuitive approach is often the most favorable to teachers as well, it would be interesting to investigate teachers' perspectives on this matter in future studies, so that teachers can modify their teaching styles to meet students' expectations because any mismatch between the two is likely to have a negative impact on the teaching and learning process. Secondly and in relation to the type of feedback given by teachers, students' belief in the value of immediate corrective feedback on pronunciation errors denotes two possible interpretations: One is that students may not have yet experienced the possible impacts of teachers' immediate correction of their errors in pronunciation classes and particularly in front of their peers, and the second relates to the possible students' self-confidence and seriousness in dealing with this subsystem.

The final insight of this study relates to students' views of the nativeness factor in teaching English pronunciation. There is a trend that has started to appear in most Gulf countries towards involving NESTs in the delivery of English language courses (see, for example, Al-Shammari, 2011). The experiences and capacities of NESTs are valued worldwide, but the extent to which students accept the notion of getting instruction from NESTs is variable because-as discussed widely in the literature (see, for example, Cook, 1999; Ma, 2012)-NESTs may not be suitable for some students, particularly those of low proficiency levels. Thus, it becomes necessary to draw on students' needs and preferences towards such inclusion of NESTs in ELT classrooms. Results of this study, for example, showed a somewhat higher level of support $(52.12 \%)$ for NNESTs in L2 pronunciation teaching than for NESTs, with 45.07\% favoring instruction from NESTs. Each group of students had their own reasons for their preference, as discussed in the previous section. All in all, students' perceptions of the roles of NESTs and NNESTs did not in the main differ from those discussed in mainstream literature on the merits of each type of teachers. NESTs, for example, were valued here because of their abilities to produce and pronounce words and utterances accurately which makes them the desired model for most students in ESL and EFL contexts (Cook, 1999). On the other hand, NNESTs were valued in the fact that they share an L1 with students (see, for example, Forman, 2010) which assists them to explain fully in L1, and to be a model for students, especially those of low proficiency levels. However, it is not only lower-level students who may favor NNESTs: as S4 indicated above, some students have experienced learning from both types of teachers and found that NNESTs could be better models for their L2 learning. As Cook (2005) and Medgyes (1994) argue, NNESTs have a deep and extensive experience of learning that L2 themselves which may greatly enhance their own teaching ability.

\section{Implications}

This paper has attempted to assist in the development of the process of pronunciation teaching in this EFL context by arguing that students should be more involved in the teaching and learning processes at the college and university levels. This involvement of students can only be possible when we understand their beliefs and expectations from a language course, and this is what the present study set out to explore. It was found that students are empowered with motivation and willingness to improve their pronunciation abilities by improving 
the ways in which pronunciation is addressed in their program. The study, therefore, provides invaluable implications for teachers, educators and administrators in this context and other similar contexts that may help to rethink the teaching of English pronunciation. First, if teachers become aware of their students' beliefs, they can adapt their teaching styles to match those of students. In addition, teachers may also start thinking about their approaches in addressing different aspects of pronunciation. For example, they may start revising their course design in light of students' expectations to learn specific features that they see as problematic to their communication in L2. Secondly, educators and administrators should take into consideration students' voices in their decision making and curriculum development. For example, students' dissatisfaction with the low attention given to pronunciation compared to areas such as grammar, reading and writing should not be ignored if the program aims to provide the workplace with proficient users of English who are capable of communicating effectively in L2.

\subsection{Limitations and Future Research}

There are some limitations to this study in terms of methodology and scope. The use of surveys-though advantaged for their potential to collect data quickly and being nonthreatening to confidentiality (Oxford \& Burry-Stock, 1995)-is limited in that deeper understandings of students' responses are usually missed. Also, the study is limited in the number of students who took part; greater number of students would have been a better sampling in order for more reliable generalizations. Further, the study would have been more representative if teachers' views were also taken into account, so that a comparison of student and teacher views would be made possible. In regard to the scope of the study, the beliefs reported here represent only a small part of what students have in mind about their language learning and teaching. Further issues need to be considered such as students' goals of learning English more broadly, their future use of the language, and their models of learning English pronunciation. Such matters can be the concern of future studies that need to explore in more depth students' expectations of as well as teachers' perspectives on the teaching of English pronunciation at university level, so as to create harmony between both learners' and teachers' expectations. As Timmis (2002, p. 240) put it, "students" views may differ from the expectations of teachers and academics, and ... it is important for us to be aware of these views."

\section{Conclusion}

It is common to read scholars' assertions about the lack of attention devoted to their areas of expertise and research, and the area of L2 pronunciation is no exception. However, it would be absurd to continue raising the same concerns over the years without engaging ourselves in both theoretical and empirical investigations into the areas that deserve more attention. This study hopes to complement efforts exerted in other studies and aims to advance knowledge about L2 pronunciation instruction. This study, concerned with investigating approaches to L2 pronunciation teaching, took a first step into improving current situations in EFL contexts by exploring learners' perspectives on how best to deal with pronunciation in class. It has provided a clear picture of the cognitive side (i.e., the beliefs) of students as participants in the process of language instruction. However, this is only a start and further research is needed to explore students' use of pronunciation learning strategies (i.e., the practical side), the effectiveness of these strategies, and the relationship with teaching itself.

\section{Acknowledgements}

I would like to express my sincere appreciation to Ross Forman for his thoughtful feedback on an earlier version of this article and to the anonymous reviewers. I am also grateful to the students who volunteered to take part in the study. Any remaining shortcomings are my own.

\section{References}

Al-Shammari, S. (2011). Investigating views of "nativeness" of English teachers in a multilingual, multicultural setting (MA thesis. UAE: American University of Sharjah).

Anthony, E. M. (1963). Approach, method and technique. ELT Journal, 17, 63-67. http://dx.doi.org/10.1093/elt/XVII.2.63

Baker, A. A., \& Murphy, J. M. (2011). Knowledge base of pronunciation teaching: Staking out the territory. TESL Canada, 28(2), 29-50.

Baker, A. A. (2011). Pronunciation pedagogy: second language teacher cognition and practice (Unpublished doctoral dissertation). Atlanta, GA: Georgia State University.

Baker, A. A. (2014). Exploring teachers' knowledge of second language pronunciation techniques: teacher cognitions, observed classroom practices, and student perceptions. TESOL Quarterly, 48, 136-163. 
http://dx.doi.org/10.1002/tesq.99

Benjamin, L. T. (2005). Setting course goals: privileges and responsibilities in a world of ideas. Teaching of Psychology, 32, 146-149. http://dx.doi.org/10.1207/s15328023top3203_1

Bernat, E. (2008). Beyond beliefs: psycho-cognitive, sociocultural and emergent ecological approaches to learner perceptions in foreign language acquisition. Asian EFL Journal, 10, 7-27.

Borg, S. (2006). Teacher cognition and language education: Research and practice. London: Continuum.

Breitkreutz, J. A., Derwing, T. M., \& Rossiter, M. J. (2001). Pronunciation teaching practices in Canada. TESL Canada Journal, 19(1), 51-61.

Brown, H. D. (2007). Principles of language learning and teaching (5th ed.). White Plains, NY: Longman.

Burgess, J., \& Spencer, S. (2000). Phonology and pronunciation in integrated language teaching and teacher education. System, 28, 191-215. http://dx.doi.org/10.1016/S0346-251X(00)00007-5

Calka, A. (2011). Pronunciation learning strategies-identification and classification. In M. Pawlak, E. Waniek-Klimczak, \& J. Majer (Eds.), Speaking and instructed foreign language acquisition (pp. 149-168). Bristol: Multilingual Matters.

Celce-Murcia, M., Brinton, D., Goodwin, J., \& Griner, B. (2010). Teaching pronunciation: A course book and reference guide (2nd ed.). Cambridge, UK: Cambridge University Press.

Cenoz, J., \& Garcia-Lecumberri, L. (1999). The acquisition of English pronunciation: learners' views. International Journal of Applied Linguistics, 9, 3-17.http://dx.doi.org/10.1111/j.1473-4192.1999.tb00157.x

Chela-Flores, B. (2001). Pronunciation and language learning: an integrative approach. International Review of Applied Linguistics in Language Teaching, 39, 85-101.http://dx.doi.org/10.1515/iral.39.2.85

Cohen, A. D. (1998). Strategies in learning and using a second language. London: Longman.

Cook, V. (1999). Going beyond the native speaker in language teaching. TESOL Quarterly, 33, 185-209. http://dx.doi.org/10.2307/3587717

Cook, V. (2005). Basing teaching on the L2 user. In E. Llurda (Ed.), Non-native language teachers: Perceptions, challenges and contributions to the profession (pp. 47-61). New York, NY: Springer. http://dx.doi.org/10.1007/0-387-24565-0_4

Cook, V. (Ed.) (2003). Effects of the second language on the first. Clevedon: Multilingual Matters.

Couper, G. (2003). The value of an explicit pronunciation syllabus in ESOL teaching. Prospect, 18(3), 53-70.

Couper, G. (2009). Teaching and learning L2 pronunciation: understanding the effectiveness of socially constructed metalanguage and critical listening in terms of a cognitive phonology framework (Unpublished doctoral dissertation). Armidale, Australia: University of New England.

Derwing, T. M., \& Munro, M. J. (2005). Second language accent and pronunciation teaching: A research-based approach. TESOL Quarterly, 39, 379-97. http://dx.doi.org/10.2307/3588486

Derwing, T. M. (2008). Curriculum issues in teaching pronunciation to second language learners. In J. G. H. Edwards, \& M. L. Zampini (Eds.), Phonology and second language acquisition (pp. 347-369). Amsterdam: John Benjamins Publishing Company. http://dx.doi.org/10.1075/sibil.36.17der

Derwing, T. M. (2010). Utopian goals for pronunciation teaching. In J. Levis, \& K. LeVelle (Eds.), Proceedings of the $1^{\text {st }}$ pronunciation in second language learning and teaching conference (pp. 24-37). Ames, IA: Iowa State University.

Derwing, T. M., Munro, M. J., \& Wiebe, G. E. (1998). Evidence in favour of a broad framework for pronunciation instruction. Language Learning, 48, 393-410. http://dx.doi.org/10.1111/0023-8333.00047

Ellis, E. (2004). The invisible multilingual teacher: the contribution of language background to Australian ESL teachers' professional knowledge and beliefs. International Journal of Multilingualism, 1, 90-108. http://dx.doi.org/10.1080/14790710408668181

Field, J. (2005). Intelligibility and the listener: the role of lexical stress. TESOL Quarterly, 39, 399-423. http://dx.doi.org/10.2307/3588487

Foote, J. A., Holtby A. K., \& Derwing, T. M. (2011). Survey of the teaching of pronunciation in adult ESL programs in Canada, 2010. TESL Canada Journal, 29(1), 1-22. 
Forman, R. (2007). Bilingual teaching in the Thai EFL context: One teacher's practice. TESOL in Context, 16, 19-24.

Forman, R. (2010). Ten principles of bilingual pedagogy in EFL. In A. Mahboob (Ed.), The NNEST lens: Non-native English speakers in TESOL (pp. 54-86). Newcastle, UK: Cambridge Scholars Publishing.

Forman, R. (2012). Six functions of bilingual EFL teacher talk: animating, translating, explaining, creating, prompting and dialoguing. RELC Journal, 43, 239-53. http://dx.doi.org/10.1177/0033688212449938

Fraser, H. (2000). Coordinating improvements in pronunciation teaching for adult learners of English as a second language. Canberra, Australia: Department of Education, Training and Youth Affairs.

Gilbert, J. B. (2008). Teaching pronunciation using the prosody pyramid. New York: Cambridge University Press.

Goodwin, J. (2001). Teaching pronunciation. In M. Celce-Murcia (Ed.), Teaching English as a second or foreign language (pp. 117-137). Boston: Heinle \& Heinle.

Goodwin, J. (2005). The power of context in teaching pronunciation. In J. Frodesen, C. Holten, \& M. Celce-Murcia (Eds.), The power of context in language teaching and learning (pp. 225-236). Australia: Thomson Heinle.

Hahn, L. D. (2004). Primary stress and intelligibility: research to motivate the teaching of suprasegmentals. TESOL Quarterly, 38, 201-23. http://dx.doi.org/10.2307/3588378

Horwitz, E. K. (2008). Why student beliefs about language learning matter: issues in the development and implementation of the beliefs about language learning inventory. In H. J. Siskin (Ed.), AAUSC 2007: From thought to action: exploring beliefs and outcomes in the foreign language program (pp. 2-8). Boston: Thomson Heinkle.

Kennedy, S. (2008). Second language learner speech and intelligibility: Instruction and environment in a university setting (Unpublished doctoral dissertation). Montreal, Canada: McGill University.

Keys, K. (2000). Discourse level phonology in the language curriculum: A review of current thinking in teaching pronunciation in EFL courses. Linguagem \& Ensino, 3(1), 89-105.

Levis, J. M. (2005). Changing contexts and shifting paradigms in pronunciation teaching. TESOL Quarterly, 39, 369-77. http://dx.doi.org/10.2307/3588485

Levis, J. M. (2007). Computer technology in teaching and researching pronunciation. Annual Review of Applied Linguistics, 27, 184-202. http://dx.doi.org/10.1017/S0267190508070098

Li, J., \& Chun, C. (2012). Effects of learning strategies on student reading literacy performance. The Reading Matrix, 12, 30-38.

Lin, C. (2010). English teachers' beliefs and practices of pronunciation teaching: a qualitative study on elementary school teachers (Unpublished MA thesis). Taiwan: National Yunlin University of Science \& Technology.

Ma, L. (2012). Advantages and disadvantages of native- and nonnative-English-speaking teachers: Student perceptions in Hong Kong. TESOL Quarterly, 46, 280-305. http://dx.doi.org/10.1002/tesq.21

MacDonald, S. (2002). Pronunciation-views and practices of reluctant teachers. Prospect, 17(3), 3-18.

Medgyes, P. (1994). The non-native teacher. London: Macmillan.

Munro, J. M., \& Derwing, T. M. (1995). Foreign accent, comprehensibility and intelligibility in the speech of $\begin{array}{lllll}\text { second language } \quad \text { learners. } & \text { Language } & \text { Learning, } & 45,\end{array}$ http://dx.doi.org/10.1111/j.1467-1770.1995.tb00963.x

Murphy, J. M. (2014). Intelligible, comprehensible, non-native models in ESL/EFL pronunciation teaching. System, 42, 258-269. http://dx.doi.org/10.1016/j.system.2013.12.007

Myers, I. B., \& Myers, P. B. (1980). Gifts differing: understanding personality type. Palo Alto, CA: Consulting Psychologists Press.

Oxford, R. L., \& Burry-Stock, J. A. (1995). Assessing the use language learning strategies worldwide with the ESL/EFL version of the Strategy Inventory for Language Learning (SILL). System, 23, 1-23. http://dx.doi.org/10.1016/0346-251X(94)00047-A

Oxford, R. L. (1990). Language learning strategies: What every teacher should know. Boston: Heinle \& Heinle 
Publishers.

Pawlak, M. (2008). Another look at the use of pronunciation learning strategies: An advanced learner's perspectives. In E. Waniek-Klimczak (Ed.), Issues in accents of English (pp. 304-322). Newcastle upon Tyne: Cambridge Scholars Publishing.

Pawlak, M. (2010). Designing and piloting a tool for the measurement of the use of pronunciation learning strategies. Research in Language, 8, 189-202. http://dx.doi.org/10.2478/v10015-010-0005-6

Pawlak, M., Mystkowska-Wiertelak, A., \& Bielak, J. (2015). Exploring advanced learners' beliefs about pronunciation instruction and their relationship with attainment. In E. Waniek-Klimczak, \& M. Pawlak (Eds.), Teaching and Researching the Pronunciation of English (pp. 3-22). Switzerland: Springer International Publishing. http://dx.doi.org/10.1007/978-3-319-11092-9_1

Porter, D. (1999). Pronunciation. In B. Spolsky (Ed.), Conciseencyclopedia of educational linguistics (pp. 647-652). Oxford, MS: Pergamon Elsevier.

Rajadurai, J. (2001). An investigation of the effectiveness of teaching pronunciation to Malaysian TESOL students. Forum, 39, 10-15.

Richards, J. C., \& Rodgers, T. S. (2001). Approaches and methods in language teaching. Cambridge: Cambridge University. http://dx.doi.org/10.1017/CBO9780511667305

Szpyra-Kozlowska, J. (2008). English pronunciation pedagogy in Poland-achievements, failures and future prospects. In E. Waniek-Klimczak (Ed.), Issues in accents of English (pp. 212-234). Newcastle upon Tyne: Cambridge Scholars Publishing.

Timmis, I. (2002). Native-speaker norms and international English: A classroom view. ELT Journal, 56, 240-9. http://dx.doi.org/10.1093/elt/56.3.240

Tubić, T., \& Hamiloğlu, K. (2009). Linking learning styles and teaching styles. In A. Swennen, \& M. van der Klink (Eds.), Becoming a teacher educator: Theory and practice for teacher educators (pp. 133-144). Amsterdam: Springer Science+Business Media. http://dx.doi.org/10.1007/978-1-4020-8874-2_10

Vandergrift, L. (1999). Facilitating second language listening comprehension: Acquiring successful strategies. ELT Journal, 53, 168-176. http://dx.doi.org/10.1093/elt/53.3.168

Wenden, A. (1986). Helping language learners think about learning. ELT Journal, 40, 3-12. http://dx.doi.org/10.1093/elt/40.1.3

White, C. (2008). Language learning strategies in independent language learning: an overview. In S. Hurd, \& T. Lewis (Eds.), Language learning strategies in independent settings (pp. 3-24). Bristol: Multilingual Matters.

Yang, N. (1999). The relationship between EFL learners' beliefs and learning strategy use. System, 27, 515-535. http://dx.doi.org/10.1016/S0346-251X(99)00048-2

Yates, L., \& Zielinski, B. (2009). Give it a go: Teaching pronunciation to adults. Retrieved from http://www.ameprc.mq.edu.au/_data/assets/pdf_file/0011/157664/interactive_sm.pdf [viewed 08.12.14]

Young, D. J. (1991). Creating a low-anxiety classroom environment: What does language anxiety research suggest? The Modern Language Journal, 75, 426-39. http://dx.doi.org/10.1111/j.1540-4781.1991.tb05378.x

\section{Appendix}

\section{Student survey}

Please tick $[\sqrt{ }]$ the square next to the appropriate answer.

\section{$>$ Background questions}

1. Age: [ ] 18-20 [ ] 21-25 [ ] 26-30

2. Year of Study:

[] $1^{\text {st }}$ year [] $2^{\text {nd }}$ year [] $3^{\text {rd }}$ year [] $4^{\text {th }}$ year +

3. How many pronunciation subjects have you studied so far?
[ ] 1 subject
[ ] 2 subjects
[ ] 3 or more
[ ] none 
4. How many pronunciation subjects does the whole curriculum include?
[ ] 1 subject
[ ] 2 subjects
[ ] 3 subjects
[ ] 4 or more

5. What is the main focus in these subjects?

[ ] Consonants and vowels $\quad[$ ] connected speech
[ ] Stress, rhythm, intonation
$[\quad]$ All the above

6. In the following table, please rate your ability in English pronunciation on the scale from 1 to 5.

$1=$ very good; 2 = good $; 3=$ average $; 4=$ fair $; 5=$ poor

\begin{tabular}{llllll}
\hline Statement & $\mathbf{1}$ & $\mathbf{2}$ & $\mathbf{3}$ & $\mathbf{4}$ & $\mathbf{5}$ \\
\hline How would you rate your English pronunciation ability & & & & & \\
\hline
\end{tabular}

\section{Perceptions of current pronunciation teaching}

7. In the following table, please tick $[\sqrt{ }]$ in the square next to the point that indicates your attitude.

$S A=$ Strongly agree; $A=$ Agree; $N=$ Neither agree nor disagree; $D=$ Disagree; $S D=$ Strongly disagree

\begin{tabular}{llllll}
\hline Statement & SA & A & N & D & SD
\end{tabular}

The amount of instruction is enough to develop my pronunciation abilities

I suggest devoting more subjects to L2 pronunciation

The course design of pronunciation needs improvement

8. Please tick $[\sqrt{ }]$ in the square next to the point that indicates your perception.

a. What exactly would you like to learn in a pronunciation subject?

[ ] All aspects of pronunciation

[ ] Only aspects that cause communication problems

[ ] Only aspects that are not problematic

[ ] Unsure

b. What language would you prefer teachers to use in pronunciation classes?

[ ] English only

[ ] Arabic only

[ ] Mix of English and Arabic

[ ] Unsure

- Why?

c. Please choose your favourite learning and teaching style.

[ ] I like to first receive teachers' explanation before I practice pronunciation

[ ] I like to first practice pronunciation and then receive explanation

[ ] I like to switch between the previous two ways

[ ] Unsure

d. What type of feedback would you prefer to receive?

[ ] Immediate feedback (as soon as I commit the mistake)

[ ] Delayed feedback (after the task is completed)

[ ] Unsure 
e. What type of teachers would you prefer to get instruction from?

[ ] Native English speaking teachers

[ ] Non-native English speaking teachers

[ ] Any of the above

[ ] Unsure

- Why?

\section{Copyrights}

Copyright for this article is retained by the author(s), with first publication rights granted to the journal.

This is an open-access article distributed under the terms and conditions of the Creative Commons Attribution license (http://creativecommons.org/licenses/by/3.0/). 